International Journal of Health Sciences
Available online at www.sciencescholar.us
Vol. 6 No. 1, April 2022, pages: 304-311
e-ISSN: 2550-696X, p-ISSN: 2550-6978
https://doi.org/10.53730/ijhs.v6n1.4189

\title{
The Actual Status of Physical Education for High School Learners Through Socializing in Vietnam
}

\author{
Q CrossMark
}

Nguyen Dang Trung a, Nguyen Thanh Trung b, Nguyen Thi Thanh Hong c, Do Xuan Duyet ${ }^{d}$, Tu Duc Van e

Manuscript submitted: 22 September 2021, Manuscript revised: 8 December 2021, Accepted for publication: 17 January 2022

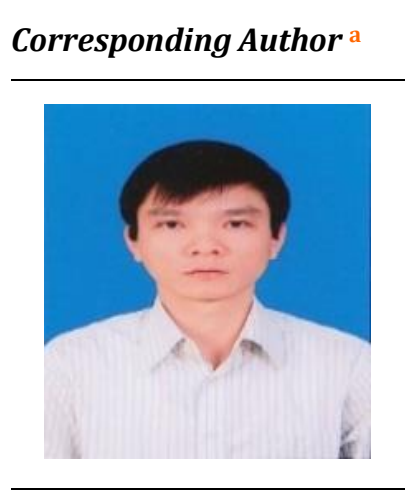

Keywords

health care;

health improvement;

healthy lifestyle;

high school education;

physical education;

protecting health;

socializing education;

teaching quality;

\begin{abstract}
The objective of the study is to evaluate the actual status of physical education program implementation and socialization of physical education in high school education in Vietnam. We designed a questionnaire using Google Form, the questionnaire consists of 15 questions including Q.1 to Q.11 related to the physical education program; Q.12 to Q.15 related to the socialization of physical education. The rating scale is divided into 4 levels (non-satisfied; partially satisfied; satisfied; well satisfied). The survey was conducted online of 345 people including education administrators and high schools teachers. Area of the survey is in Hanoi city, Lai Chau province. The study shows that the actual implementation of physical education programs in high schools has not met the targets of the 2018 high school education program promulgated by the Ministry of Education and Training of Vietnam; for socializing physical education activities, there are still many limitations, socialization activities have not had much positive impact on the quality of teaching physical education subject in high schools.
\end{abstract}

International Journal of Health Sciences (C) 2022. This is an open access article under the CC BY-NC-ND license (https://creativecommons.org/licenses/by-nc-nd/4.0/).

\section{Contents}

Abstract

1 Introduction.

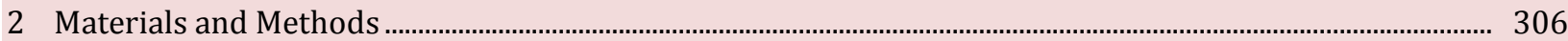

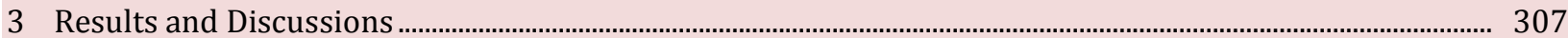

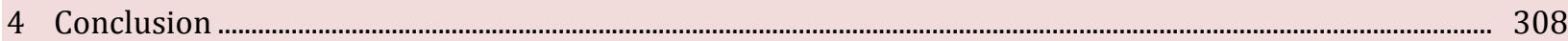

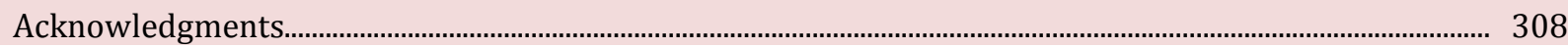

a Ha Noi Metropolitan University, Hanoi, Viet Nam

b Hanoi National University of Education, Hanoi, Viet Nam

c Hanoi National University of Education, Hanoi, Viet Nam

d Hanoi National University of Education, Hanoi, Viet Nam

e Hanoi National University of Education, Hanoi, Viet Nam 
References .

\section{Introduction}

In high schools, physical education activities contribute to the proper development of physical fitness and the improvement of health, the development of operational qualities, perfecting operating skills and techniques, forming a sustainable interest and a need to exercise systematically; at the same time arming knowledge, forming for students the habit of maintaining hygiene, protecting health, having a healthy lifestyle (Frank et al., 2021; O'Bryant et al., 2000). Therefore, physical education for students in schools has always received the attention of the government, the education sector, and schools (Hushman, 2013; Trung \& Son, 2009).

To achieve quality and effectiveness, educational activities in general and physical education activities for high school students, in particular, need not only the reliability of the school educational force but also the participation of family and social educational forces (Valtonen et al., 2015; Duc et al., 2016; Andrew et al., 2018). The Education for All (EFA) vision proposed by UNESCO along with United Nations and countries around the world in 1990 in Thailand has shown the importance of socializing education (Cekaite, 2013; Pea, 1987), especially the importance and responsibilities of schools, families, and communities in developing education (Richards \& Gaudreault, 2016; Richards et al., 2018; Khanh et al., 2021, MOET, 2018).

In Japan: Japan has always actively reformed the education system, emphasizing the development of human potential, building a system of educational development principles with the following policy: Strengthening and diversifying investments in education. The Japanese Senate has passed 3 bills on education reform: Law on School Education; Law on Local Education Management and Law on Social Education (Diachenko et al., 2021). Japan is a country that has succeeded in implementing the policy of equality and the right to education for all, education regardless of class, status, religion, emphasizing talent discovery and fostering talents for the nation, humanizing educational environment, bringing Japanese education to catch up with the world (Trung, etc., 2021; Widana et al., 2021).

In the US: The US government has carried out a revolution in education standardization (Standards revolution). To do this, one of the solutions that the Government is focusing on is implementing the policy of diversifying and developing the form of public-private schools. American education is especially interested in building an education based on the foundation of information technology and knowledge society that can meet and anticipate the development of the market economy, aiming for the following targets: Everyone can have opportunities for lifelong learning, heading towards mass education, with the policy of empowering local authorities to manage school education and diversifying education forms: formal education, continuing education, education from society, online education (Trung, etc., 2021; Trung \& Son, 2009).

In Singapore: Singapore is a commercial, financial center and currently the educational center of all countries in the region, a nation that ensures the quality of education by international and regional standards. Singapore is a successful country in promoting resources from society and the world for building and developing the nation's education system (Lytvyn et al., 2021). The slogan of the country is: "The school of thinking, the notion of learning". It can be affirmed that, although the nature of education in different countries is different, the common point is to mobilize all resources and conditions for developing education (Rau et al., 2008; Germeijs \& Verschueren, 2007). In developed countries, the focus is on investing in education through the process of mobilizing the power of the state and social classes, raising the level of knowledge, bringing people's intellectual level to the level of the era for people to master industrial and postindustrial civilizations. In developing countries, mobilizing resources for education is the best method to improve the quality of human resources, enrich talents and intelligence to serve socio-economic development goals. Proper investment in people will create a premise for stability and sustainable development in developing countries (Trung etc., 2021; Trung \& Son, 2009).

In Vietnam, the 2018 High school Education Program was promulgated according to Circular No. 32/2018/TT-BGDĐT on December 26, 2018, defining physical education as a compulsory subject from grade 1 to grade 12, the general goal of physical education activities for high school students is to develop health care abilities, basic exercise, and sports skills, and to develop students' physical qualities; to help students to develop both their physical and mental harmoniously; to have the good qualities and capabilities necessary to Trung, N. D., Trung, N. T., Hong, N. T. T., Duyet, D. X., \& Van, T. D. (2022). The actual status of physical education for high school learners through socializing in Vietnam. International Journal of Health Sciences, 6(1), 304-311. https://doi.org/10.53730/ijhs.v6n1.4189 
become responsible citizens and healthy, cultured, industrious, creative workers who meet individual development needs and requirements of the cause of building and defending the country in the era of globalization and the new industrial revolution (Kern et al., 2019; Templin \& Richards, 2014). The above goal can only be achieved most often and effectively through way of socialization (MOET, 2018). Therefore, the actual status of physical education activities for high school students through socialization compared to the requirements of the 2018 high school education program is an issue that needs to be studied (Geisler, 2017).

\section{Materials and Methods}

The objective of the study: Assessing the status of implementing the physical education program and the socialization of physical education in high school education in Vietnam, in which the issue of socializing physical education is considered as a factor that helps improve the quality of physical education for students, the quality of the school's comprehensive education.

The subject of the study: Physical education program and socializing physical education in high school education.

Scope of the study: Survey subjects: Surveyed 345 people including educational administrators, teachers of high schools, officials of agencies, departments, and organizations. Survey area: Hanoi city, Lai Chau province. Survey tool: The survey form is designed using Google Form; an online survey form.

The questionnaire consists of 15 questions, with 4 rating levels (non-satisfied; partially satisfied; satisfied; well satisfied).

Table 1

The questionnaire consists of 15 questions, with 4 rating levels (non-satisfied; partially satisfied; satisfied; well satisfied)

\begin{tabular}{ll}
\hline Question code & Questionnaire \\
\hline Q.1 & Meeting the goals of high school education. \\
Q.2 & Meeting the training goals of the physical education field. \\
Q.3 & Adjusting periodically to improve quality. \\
The physical education program for high school students is suitable for Vietnam and \\
international integration. \\
The physical education program for high school students is suitable to the reality of \\
Vietnam and international integration. \\
The physical education program for high school students meets professional \\
requirements, ethics, school culture, and community culture. \\
Q.8 & $\begin{array}{l}\text { The physical education program for high school students is associated with the } \\
\text { human resource development strategy, education, and exercise/sport policies of the }\end{array}$ \\
nation and heading towards international integration. \\
Q.10 & $\begin{array}{l}\text { Core issues of knowledge, skills, and attitudes in exercise/sport. } \\
\text { The content manages, teaches, and develops physical training and exercise/sports }\end{array}$ \\
Q.12 & $\begin{array}{l}\text { Thevements. } \\
\text { The content focuses on legal issues and professional ethics. }\end{array}$ \\
Refer to a reputable training program in the country or the world. \\
The participation of sports scientists, athletes, lecturers, managers. \\
The participation of social organizations, sponsors for projects supporting physical \\
\end{tabular}


Analyze and explain:

Theoretical research methods: Analyzing and synthesizing basic theoretical basis as a foundation and orientation for practical research.

Mathematical statistical methods: Using mathematical formulas to process survey results.

Accordingly, making assessments related to the implementation of physical education programs and socializing physical education activities.

\section{Results and Discussions}

Table 1

The actual state of implementing a physical education program for high school students and activities of socializing physical education

\begin{tabular}{lllllllll}
\hline \multirow{2}{*}{ Question } & \multicolumn{2}{c}{ Non-satisfied } & \multicolumn{2}{c}{ Partially satisfied } & \multicolumn{2}{c}{ Satisfied } & \multicolumn{2}{c}{ Well satisfied } \\
\cline { 2 - 8 } & Quantity & Percent & Quantity & Percent & Quantity & Percent & Quantity & Percent \\
\hline Q.1 & 94 & 26.55 & 156 & 44.07 & 57 & 16.10 & 38 & 10.73 \\
Q.2 & 83 & 23.45 & 161 & 45.48 & 69 & 19.49 & 32 & 9.04 \\
Q.3 & 48 & 13.56 & 203 & 57.34 & 43 & 12.15 & 51 & 14.41 \\
Q.4 & 102 & 28.81 & 173 & 48.87 & 49 & 13.84 & 21 & 5.93 \\
Q.5 & 107 & 30.23 & 168 & 47.46 & 51 & 14.41 & 19 & 5.37 \\
Q.6 & 75 & 21.19 & 194 & 54.80 & 61 & 17.23 & 15 & 4.24 \\
Q.7 & 113 & 31.92 & 165 & 46.61 & 35 & 9.89 & 32 & 9.04 \\
Q.8 & 81 & 22.88 & 198 & 55.93 & 36 & 10.17 & 30 & 8.47 \\
Q.9 & 71 & 20.06 & 176 & 49.72 & 51 & 14.41 & 47 & 13.28 \\
Q.10 & 67 & 18.93 & 152 & 42.94 & 66 & 18.64 & 60 & 16.95 \\
Q.11 & 178 & 50.28 & 123 & 34.75 & 32 & 9.04 & 12 & 3.39 \\
Q.12 & 152 & 42.94 & 135 & 38.14 & 45 & 12.71 & 13 & 3.67 \\
Q.13 & 158 & 44.63 & 153 & 43.22 & 18 & 5.08 & 16 & 4.52 \\
Q.14 & 102 & 28.81 & 184 & 51.98 & 34 & 9.60 & 25 & 7.06 \\
Q.15 & 117 & 33.05 & 168 & 47.46 & 42 & 11.86 & 18 & 5.08 \\
\hline
\end{tabular}

The survey results show that in Q.1, 26.55\% of respondents rated as Non-satisfied; $44.07 \%$ assessed Partially satisfied; assessment of Satisfied and Well satisfied is $16.05 \%$ and $10.73 \%$, respectively, which is quite low. Meanwhile, the surveyed teachers assessed the training targets of the physical education sector (Q.2), with the percentage expressed in the levels of Non-satisfied, Partially satisfied, Satisfied, and Well satisfied are 23.45, 45.48, 19.49, 9.04 respectively (Hassandra et al., 2003).

Similarly, regarding items about physical education program from Q.3 to Q.11, we found that the nonsatisfied rate remained high $(13.56,28.81,30.23,21.19,31.92,22.88,20.06,18.93,50.28)$ respectively, being the highest is Q.11, with the item of "Refer to a reputable training program in the country or the world", according to what we know, most teachers ignore or rarely learn about the modern educational program or do deep research, we get many answers with the same result, teachers consider physical education as an additional subject and the study of it is only because of the compulsion of the education program, as a result, physical education teachers have not yet promoted their motivation to work, and the lack of motivation to innovate teaching methods (Daumiller et al., 2021; Pavlina et al., 2011). Meanwhile, the percentage of Satisfied in turn from Q.3 to Q.12 are (12.15, 13.84, 14.41, 17.23, 9.89, 10.17, 14.41, 18.64, 9.04, 12.71), and Well satisfied percentage are $(14.41,5.93,5.37,4.24,9.04,8.47,13.28,16.95,3.39,3.67)$ respectively. Thus, it can be seen that the terms in the physical education program from Q.3 to Q.12 are still very limited (Koka \& Hein, 2003; Wahyuni \& Widyaningsih, 2021; Cox et al., 2008).

For the questions from Q.12 to Q.15, we discovered that: With the item "The participation of sports scientists, athletes, lecturers, managers", we got the percentage of the rating from nonsatisfied, partially

Trung, N. D., Trung, N. T., Hong, N. T. T., Duyet, D. X., \& Van, T. D. (2022). The actual status of physical education for high school learners through socializing in Vietnam. International Journal of Health Sciences, 6(1), 304-311. https://doi.org/10.53730/ijhs.v6n1.4189 
satisfied, satisfied and well satisfied respectively are $(42.94,38.14,12.71,3.67)$, with the high percentage of non-satisfied and partially satisfied, while the total satisfying rate and well-satisfied rate are less than $17 \%$.

Surveying the participation of social organizations, sponsors of projects for physical education and sports, the percentage is $(44.63,43.22,5.08,4.52)$ respectively. It can be seen that, at the moment, social organizations and donors in the locals have not paid much attention to physical education or paid less attention to the aspect that has a minor impact on the innovation of teaching methods for physical education, therefore the quality of physical education in high schools has also not been improved (Graham et al., 2020; Tinh, 2021).

Regarding the act of attracting investment resources for physical education, we got the results with the rate of $28.81 \%$ non-satisfied, $51.98 \%$ partially satisfied, so only around $17 \%$ are considered to be satisfied and well satisfied, which is quite low. Similarly, in the item "The locals consider investment in physical education and sports programs as a factor to improve the quality of human resources in the future", we received a high rate for Non satisfied, while Satisfied and Well satisfied rates are low.

\section{Conclusion}

The research results are partly similar to the studies of (Trung \& Son 2009; Hushman, 2013; Richards et al., 2018), the authors all stated that the socialization of physical education is the correct and effective orientation in physical education for high school students. Therefore, the research team has made some suggestions to increase the effectiveness of physical education activities for high school students, including: (1) Regularly propagate to raise society's awareness about physical education and sport in schools; (2) Keep on research to improve the management system of physical education; (3) Renovate physical education, aiming to emphasize and improve the quality of regular and extra-curricular classes; (4) Promulgate appropriate policies and regimes; (5) Update knowledge to improve the qualifications of teachers, lecturers, volunteers, full-time and part-time guides; (6) Renovate contents, programs and forms of activities in physical education and school sports; promote scientific research in physical education sector; regularly improve teaching methods; (7) Ensure minimum required facilities for schools according to the regulations of the 2018 high school education program; (8) Encourage students to participate in extracurricular sports exercise; (9) Strengthen sports activities in schools towards socialization to attract investing participation of social organizations; (10) Regularly associate sports activities with nutrition education, ethics and lifestyle education, physical education, intellectual and spiritual education.

\section{Acknowledgments}

This work was supported by the Research Fund provided by the Ministry of Education and Training, Vietnam (The subject code: B2021-SPH-09). We are grateful to two anonymous reviewers for their valuable comments on the earlier version of this paper. 


\section{References}

Cekaite, A. (2013). Socializing emotionally and morally appropriate peer group conduct through classroom discourse. Linguistics and Education, 24(4), 511-522. https://doi.org/10.1016/j.linged.2013.07.001

Cox, A. E., Smith, A. L., \& Williams, L. (2008). Change in physical education motivation and physical activity behavior during middle school.Journal of adolescent health,43(5), 506-513. https://doi.org/10.1016/j.jadohealth.2008.04.020

Daumiller, M., Rinas, R., Hein, J., Janke, S., Dickhäuser, O., \& Dresel, M. (2021). Shifting from face-to-face to online teaching during COVID-19: The role of university faculty achievement goals for attitudes towards this sudden change, and their relevance for burnout/engagement and student evaluations of teaching quality. Computers in Human Behavior, 118, 106677. https://doi.org/10.1016/j.chb.2020.106677

Diachenko, A., Vusyk, H., Bielova, Y., Shurdenko, M., \& Titenko, O. (2021). The educational role in COVID-19 terms of ethnodesign graphic function in higher education practical activities. International Journal of Health Sciences, 5(3), 584-593. https://doi.org/10.53730/ijhs.v5n3.2540

Frank, C., Bekemeier, K., \& Menze-Sonneck, A. (2021). Imagery training in school-based physical education improves the performance and the mental representation of a complex action in comprehensive school students. Psychology of Sport and Exercise, 56, 101972. https://doi.org/10.1016/j.psychsport.2021.101972

Geisler, T. M. (2017). Examining the socialization of physical education teachers: A case study. The University of Vermont and State Agricultural College.

Germeijs, V., \& Verschueren, K. (2007). High school students' career decision-making process: Consequences for choice implementation in higher education. Journal of vocational behavior, 70(2), 223-241. https://doi.org/10.1016/j.jvb.2006.10.004

Graham, L. J., White, S. L., Cologon, K., \& Pianta, R. C. (2020). Do teachers' years of experience make a difference in the quality of teaching?. Teaching and teacher education, 96, 103190. https://doi.org/10.1016/j.tate.2020.103190

Hassandra, M., Goudas, M., \& Chroni, S. (2003). Examining factors associated with intrinsic motivation in physical education: a qualitative approach. Psychology of sport and exercise, 4(3), 211-223. https://doi.org/10.1016/S1469-0292(02)00006-7

Hushman, G. (2013). Investigating the impact of teacher socialization on a physical education teacher candidate during the student teaching process. Teacher Education Quarterly, 40(4), 81-92.

Kern, B. D., Graber, K. C., Woods, A. M., \& Templin, T. (2019). The influence of socializing agents and teaching context among teachers of different dispositions toward change.Journal of Teaching in Physical Education, 38(3), 252-261.

Khanh, M. Q., Tinh, T. T., Giang, T. T., Hong, N. T. T., Kien, P. T., \& Quang, N. V. (2021). The process of forming students' pedagogical professionalism: A case study at Hanoi National University of Education in Vietnam. Linguistics and Culture Review, 5(S3), 704-712.

Koka, A., \& Hein, V. (2003). Perceptions of teacher's feedback and learning environment as predictors of intrinsic motivation in physical education. Psychology of sport and exercise, 4(4), 333-346. https://doi.org/10.1016/S1469-0292(02)00012-2

Lytvyn, V., Akimova, O., Kuznetsova, H., Zenchenko, T., Stepanenko, O., \& Koreneva, I. (2021). The use of synchronous and asynchronous teaching methods in pedagogical education in COVID-19 terms. International Journal of Health Sciences, 5(3), 617-629. https://doi.org/10.53730/ijhs.v5n3.2681

MOET - Ministry of Education and Training, Vietnam (2018). The 2018 High school Education Program was promulgated according to Circular No. 32/2018/TT-BGDDT on December 26, 2018.

N.T. Trung etc. (2021). Physical education for high school learners through socializing and the requirements of the 2018 high school education program. Ministry of Education and Training, Vietnam, The subject code: B2021 -SPH -09.

N.T. Trung, H.D. Son (2009). Renovating the training of physical education and sports teachers - an urgent need of educational practice. Journal of Sports Science, No. 01/2009 - Institute of Sports Science, Hanoi.

O'Bryant, C. P., O'Sullivan, M., \& Raudensky, J. (2000). Socialization of prospective physical education teachers: The story of new blood. Sport, education and society, 5(2), 177-193.

P.D. Duc, T.T.H. Tuyen, L.T.T. Hoai, N.T. Huyen, H.T. Dong, N.T. Ngoc, N.V. Quy (2016). Creating a university physical education curriculum to develop capacity pedagogy. Journal of Science of HNUE, Educational Sci., 61, (6), 131-138.

Trung, N. D., Trung, N. T., Hong, N. T. T., Duyet, D. X., \& Van, T. D. (2022). The actual status of physical education for high school learners through socializing in Vietnam. International Journal of Health Sciences, 6(1), 304-311. 
Pavlina, K., Zorica, M. B., \& Pongrac, A. (2011). Student perception of teaching quality in higher $\begin{array}{llll}\text { education. Procedia-Social and } & \text { Behavioral }\end{array}$ https://doi.org/10.1016/j.sbspro.2011.04.095

Pea, R. D. (1987). Socializing the knowledge transfer problem. International journal of educational research, 11(6), 639-663. https://doi.org/10.1016/0883-0355(87)90007-3

Rau, P. L. P., Gao, Q., \& Wu, L. M. (2008). Using mobile communication technology in high school education: Motivation, pressure, and learning performance. Computers \& Education, 50(1), 1-22. https://doi.org/10.1016/j.compedu.2006.03.008

Richards, K. A. R., \& Gaudreault, K. L. (Eds.). (2016). Teacher socialization in physical education: New perspectives. Taylor \& Francis.

Richards, K. A. R., Housner, L. D., \& Templin, T. J. (2018). Addressing physical education teacher socialization through standards-based reform of physical education teacher education. Quest, 70(3), 334-353.

Templin, T. J., \& Richards, K. A. R. (2014). CH McCloy Lecture: Reflections on socialization into physical education: An intergenerational perspective. Research quarterly for exercise and sport, 85(4), 431-445.

Tinh, T. T. (2021). Research on autonomy and accountability of high schools in Vietnam. International Journal of Linguistics, Literature and Culture, 7(6), 459-467.

Valtonen, J., Reunamo, J., Hirvensalo, M., \& Ruismäki, H. (2015). Socialization into teaching physical educationAcculturative formation of perceived strengths. The European Journal of Social \& Behavioural Sciences, 12 (20 January 2015).

Wahyuni, I. S., \& Widyaningsih, E. B. (2021). Intervention with Fe supplementations and IEC about anemia against hemoglobin levels in female teenagers in state senior high school. International Journal of Health \& Medical Sciences, 4(1), 38-43.

Widana, I.K., Sumetri, N.W., Sutapa, I.K., Suryasa, W. (2021). Anthropometric measures for better cardiovascular and musculoskeletal health. Computer Applications in Engineering Education, 29(3), 550561. https://doi.org/10.1002/cae.22202 


\section{Biography of Authors}

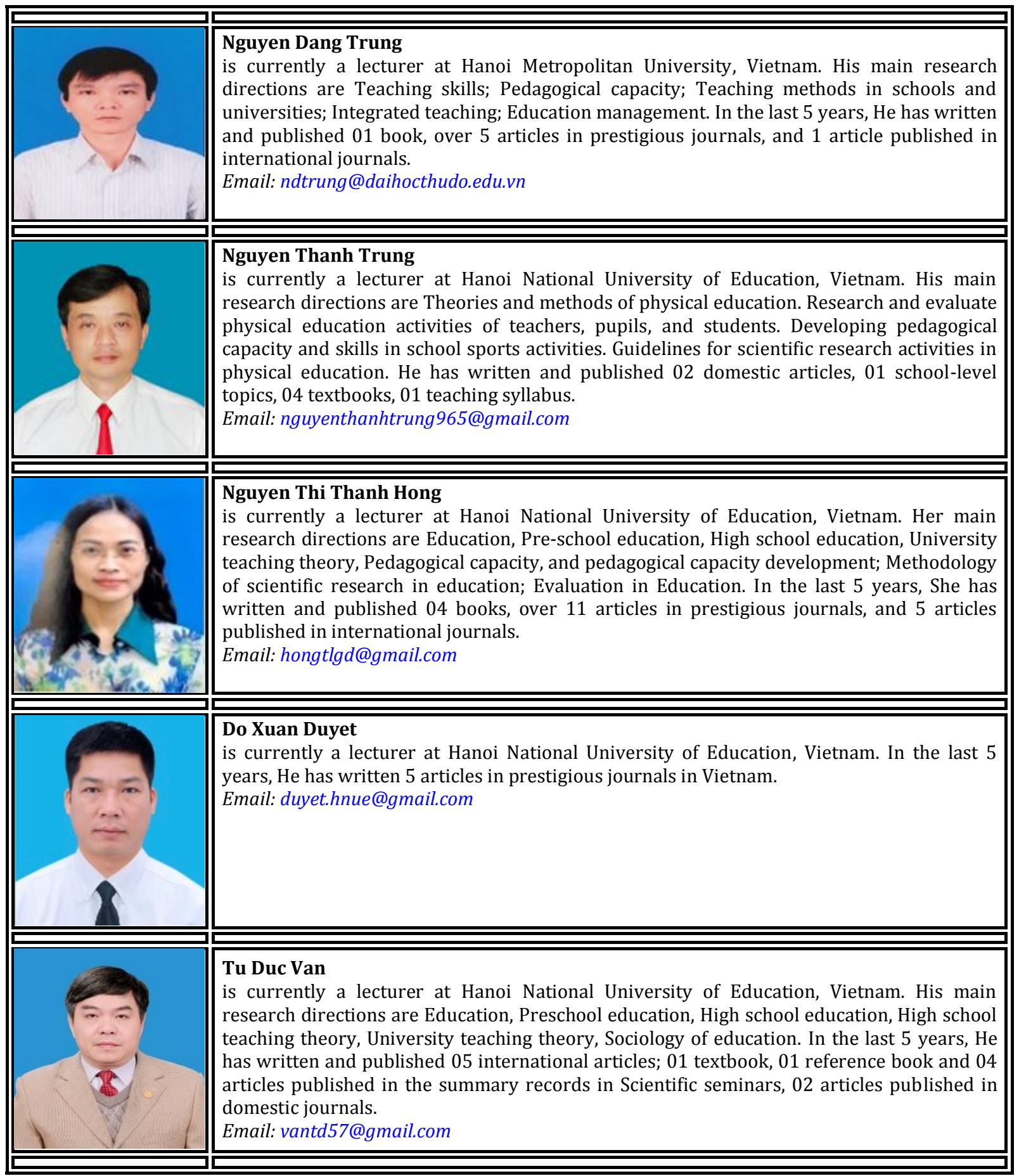

Trung, N. D., Trung, N. T., Hong, N. T. T., Duyet, D. X., \& Van, T. D. (2022). The actual status of physical education for high school learners through socializing in Vietnam. International Journal of Health Sciences, 6(1), 304-311. https://doi.org/10.53730/ijhs.v6n1.4189 